\title{
Analytical Control of a Starter Pig Feed Medicated with Amoxicillin
}

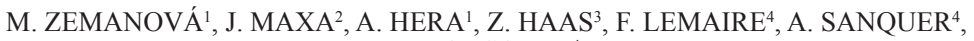 \\ E. BOUSQUET ${ }^{4}$ \\ ${ }^{1}$ Department of Pharmacology, Faculty of Veterinary Medicine, University of Veterinary \\ and Pharmaceutical Sciences, Brno, Czech Republic \\ ${ }^{2}$ Institute for the State Control of Veterinary Biologicals and Medicaments, Brno, Czech Republic \\ ${ }^{3}$ Virbac, Praha, Czech Republic \\ ${ }^{4}$ Virbac, Carros, France \\ Received April 2, 2007 \\ Accepted April 14, 2008
}

\begin{abstract}
Zemanová M., J. Maxa, A. Hera, Z. Haas, F. Lemaire, A. Sanquer, E. Bousquet: Analytical Control of a Starter Pig Feed Medicated with Amoxicillin. Acta Vet. Brno 2008, 77: 341-345.

Amoxicillin concentrations were determined by two independent laboratories for a pig starter feed medicated from a coated amoxicillin premix. The analytical method was previously transferred from one laboratory to the other one. The data between the two laboratories were consistent, showing ruggedness of the assay. Mean amoxicillin feed concentrations before and after pelletization were higher than $90 \%$ of the theoretical content, confirming satisfactory stability of this active ingredient in the coated form tested.
\end{abstract}

Beta-lactams, assay, piglet, medication, pelletization

Medicated feed is a valuable vehicle for oral collective antibiotic treatments in pigs provided that an adequate amount of the active ingredient is available for animals. Amoxicillin is used in feed for the control of Streptococcus suis and Haemophilus parasuis infections which induce significant diseases in pigs throughout the world (Higgins and Gottschalk 2006; Rapp-Gabrielson et al. 2006). This beta-lactam compound is still active on most Streptococcus suis and Haemophilus parasuis strains isolated from pigs (Marie et al. 2002; Pejsak et al. 2005; Schwarz et al 2007, 2008). The interest of an amoxicillin coating has been reported to protect this active ingredient from degradation during feed manufacturing process (Derrieu et al. 2000; Bousquet et al. 2006). The objectives of this study were to control amoxicillin concentration in an industrial feed batch before and after pelletization, and to compare analytical results of two different laboratories on the same feed samples.

\section{Materials and Methods}

Feed manufacture and sampling

A batch of starter pig feed (SKS Starter, SKS Marefy, Czech Republic) prepared in industrial conditions (batch size: $2 \mathrm{~T}$ ) was supplemented by incorporation of an amoxicillin-medicated premix (Suramox ${ }^{\circledR}$, Virbac) at the theoretical concentration of $400 \mathrm{mg}$ amoxicillin per $\mathrm{kg}$ feed. The complete feed contained nitrogen substances (18.6\%), fat (4.6\%), lysine (1.2\%), vitamin A (14 $000 \mathrm{IU} / \mathrm{kg})$, vitamin D3 (2 $100 \mathrm{IU} / \mathrm{kg})$, vitamin E $(95 \mathrm{mg} / \mathrm{kg})$, copper sulphate $(155 \mathrm{mg} / \mathrm{kg})$, enzymes and no other antimicrobial except amoxicillin. One flour sample of blank feed was taken before incorporation of the medicated premix which was then incorporated to flour feed in a horizontal mixer (Ribon mixer 6000) after accurate weighing. Duration of mixing was 6 min before incorporation of the medicated premix and again 6 min after premix introduction. Ten flour feed samples of $500 \mathrm{~g}$ each were taken after mixing. Ten $500 \mathrm{~g}$ pelleted feed samples were then taken after the cooling of pellets. Pelletization apparatus CPM 3200 was used. Steam pressure during pelletization was equal to 2 bars and the temperature of feed after pelletization was equal to $70^{\circ} \mathrm{C}$. All feed samples were divided in 2 equal parts packed in plastic bags. One set of samples was sent to each laboratory and stored at $+4{ }^{\circ} \mathrm{C}$ pending assay (Institute for the State Control of Veterinary Biologicals and Medicaments

Address for correspondence:

PharmDr. Jaroslav Maxa, PhD.

Institute for the State Control of Veterinary Biologicals and Medicaments

Hudcova 56a

Phone: +420541518243

62100 Brno, Czech Republic

E-mail:maxa@uskvbl.cz

http://www.vfu.cz/acta-vet/actavet.htm 
$=$ Laboratory 1, Brno, Czech Republic and Virbac Pharmaceutical Development Laboratory $=$ Laboratory

2, Carros, France).

Feed samples preparation

In both laboratories, a $100 \mathrm{~g}$ part of each flour or pelleted sample was crushed; then 2 independent aliquots (10 to $20 \mathrm{~g}$ ) of each sample were processed through a solid/liquid extraction with an acetonitrile/water mixture. Twenty values of amoxicillin concentration were determined by each laboratory for each type of feed (flour or pelleted).

Chromatographic conditions

High Performance Liquid Chromatography (HPLC) separations were performed on a $250 \mathrm{~mm} \times 4.6 \mathrm{~mm}, 5 \mu \mathrm{m}$ Alltima C18 column (Alltech, USA). The mobile phase was a mixture of acetonitrile and buffer solution ( $\mathrm{pH} 5.0$ ). The injection volume was $20 \mu \mathrm{l}$, the flow rate was $1 \mathrm{ml} / \mathrm{min}$, the column temperature was maintained at $25^{\circ} \mathrm{C}$ and the detection wavelength was $230 \mathrm{~nm}$.

Amoxicillin concentration calculations

Concentrations in all feed aliquots were calculated by reference to a standard solution after correction by extraction yield previously determined from spiking of the blank feed.

Statistics

Feed amoxicillin concentration was analysed according to a three-way analysis of variance using as variables the type of feed (flour vs. pelleted), laboratory and sample (nested in feed variable). The statistical analysis was performed using the 20 values for each laboratory and type of feed, respectively. Statistical software used was S-PLUS 6.2 (Insightful Corporation, Seattle WA 2001).

\section{Results}

Amoxicillin retention time ranged between 9.5 and $11 \mathrm{~min}$ in both laboratories either from flour or pelleted feed samples. Chromatograms were similar in laboratories 1 and 2 (Fig. 1).

Table 1. Mean feed amoxicillin concentrations $(\mathrm{mg} / \mathrm{kg})$

\begin{tabular}{|l|c|c|}
\hline & Flour feed & Pelleted feed \\
& $\mathrm{M} \pm \mathrm{SD}(\mathrm{mg} / \mathrm{kg})(\mathrm{N})$ & $\mathrm{M} \pm \mathrm{SD}(\mathrm{mg} / \mathrm{kg})(\mathrm{N})$ \\
$\mathrm{CV}(\%)$ & $\mathrm{CV}(\%)$ \\
\hline Laboratory 1 & $383.9 \pm 31.7(20)$ & $370.8 \pm 13.1(20)$ \\
& $(8.3 \%)$ & $(3.5 \%)$ \\
\hline Laboratory 2 & $376.9 \pm 34.7(20)$ & $365.5 \pm 42.2(20)$ \\
& $(9.2 \%)$ & $(11.5 \%)$ \\
\hline Total & $380.4^{*} \pm 33.0(40)$ & $368.2^{* *} \pm 30.9(40)$ \\
& $(8.7 \%)$ & $(8.4 \%)$ \\
\hline
\end{tabular}

$\mathrm{M}$ : mean, SD: standard deviation, $\mathrm{N}$ : number of analysis

$\mathrm{CV}$ : coefficient of variation

${ }^{*, * *}$ : values with different superscripts are significantly different $(p<0.05)$ account all analyses from both laboratories.

The mean concentration was higher in flour than in the pelleted feed $(p<0.05)$, corresponding to $95.1 \%$ and $92.0 \%$, respectively, of the theoretical concentration $(400 \mathrm{mg} / \mathrm{kg})$. Within flour or pelleted feed, concentrations were significantly different between samples $(p<0.0005)$.

\section{Discussion}

Different issues must be addressed to study concentration of an active ingredient in a medicated feed. Firstly, the site(s) of sampling in the plant must be defined (for example, after mixing for flour samples, and after pelletization and cooling for pelleted samples). Then the number and size of samples have to be determined (a minimum of 3 samples weighing at least $300 \mathrm{~g}$ each is recommended per batch both before and after pelletization). A blank feed sample from the same formula is also required to check specificity, repeatability of 
Laboratory 1
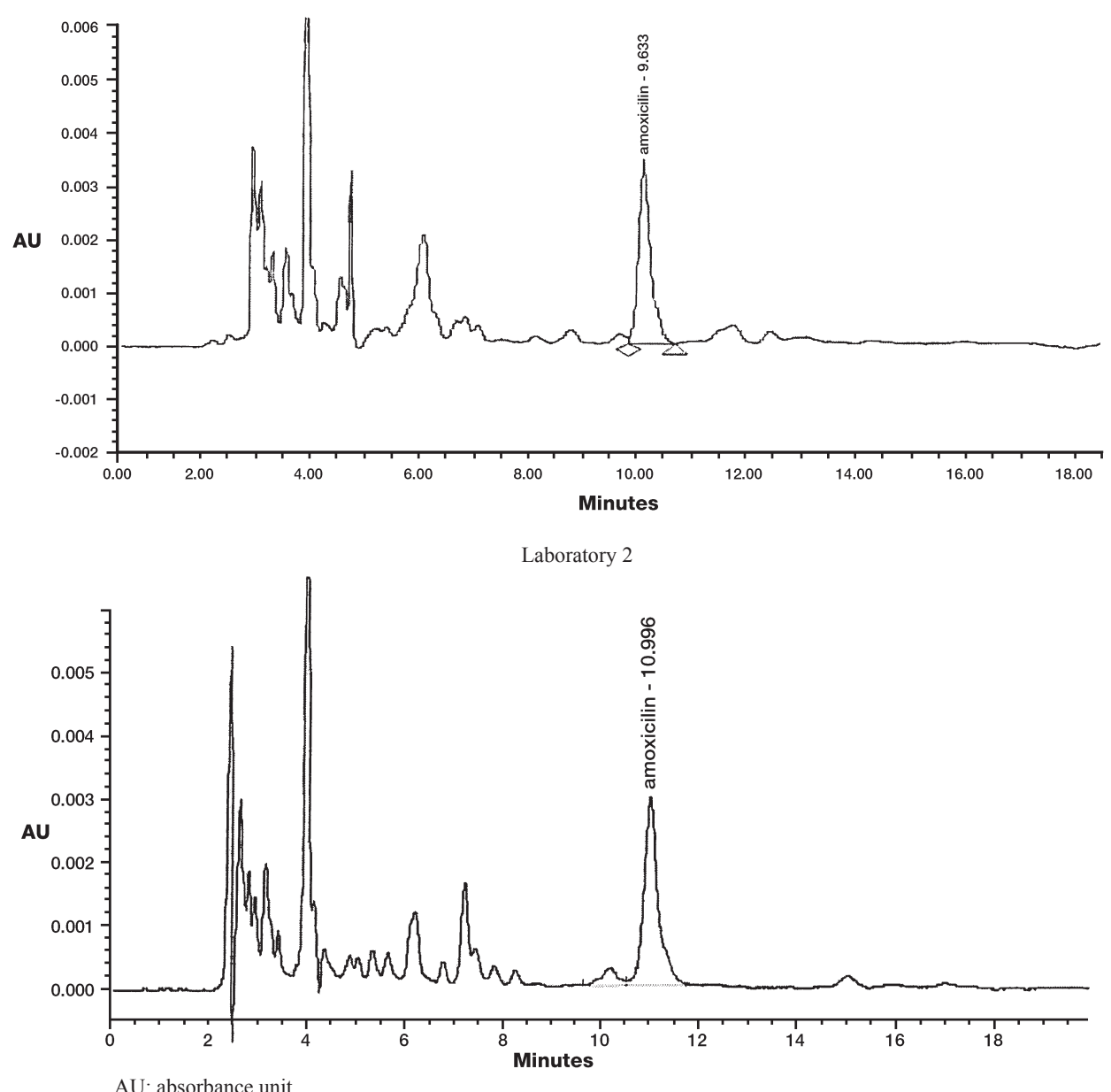

Fig. 1. Amoxicillin chromatograms from pelleted feed samples

the assay and to measure its extraction yield. This is particularly true for amoxicillin where the detection wavelength corresponds often to the absorbance of various feed components. In such case, chromatographic conditions must be adapted to resolve peaks interference. Moreover, adsorption of amoxicillin with feed ingredients may occur, possibly decreasing the extraction yield. If recovery rate is below $90 \%$, improvement of the extraction step is recommended before analysis of samples. At last, quick transport of samples to a laboratory and storage at $+4{ }^{\circ} \mathrm{C}$ pending assay are required to avoid active ingredient degradation. All these issues were respected in the present study.

The HPLC assay used in this study was developed by laboratory 2 from the reference amoxicillin method of analysis (European Pharmacopoeia 2005) completed by original extraction procedure adapted to feed samples. This analytical method used in both laboratories led to mean concentrations very close, reflecting ruggedness of the assay and satisfactory transfer from laboratory 2 to laboratory 1 . The main difference consisted of a lower coefficient of variation for pelleted feed samples in laboratory 1 . The origin of this difference is not known. 
Such type of analytical method has been previously described for amoxicillin assay in medicated premixes (Dousa and Hosmanová 2005). A liquid chromatographic tandem mass spectrometric method for amoxicillin assay in feed has been also reported (De Baere and De Backer 2007). Nevertheless, such method cannot be considered routine, enhancing the interest of the HPLC method presented here.

The feed amoxicillin concentration tested here $(400 \mathrm{mg} / \mathrm{kg})$ corresponds to the usually recommended level equivalent to a 15 to $20 \mathrm{mg} / \mathrm{kg} \mathrm{bw} / \mathrm{d}$ dose regimen in pigs according to usual feed consumptions. Such posology is consistent with pharmacology of amoxicillin against Streptococcus suis and Haemophilus parasuis (Schwarz et al. 2008).

Deviation between theoretical amoxicillin concentration and mean concentration in flour feed was lower in the present study (4.9\%) than in a recent publication $(11.1 \%)$ where raw amoxicillin was incorporated to an industrial batch of flour pig feed (De Baere and De Backer 2007). Moreover, the difference between mean flour and pelleted feed concentrations in the present study, although significant, accounted only for $3.1 \%$ of the theoretical concentration without biological relevance. The corresponding difference was much higher $(20-40 \%)$ in other studies where raw amoxicillin was incorporated into the feed (Derrieu et al. 2000, Bousquet et al. 2006). These findings confirm the interest of the coating process tested to prevent amoxicillin degradation and thus to achieve targeted posology.

The variability within flour samples on one side and pelleted samples on the other may be explained by the low amount of feed taken for each extraction/analysis procedure (10 to $20 \mathrm{~g}$ ). This amount is lower than the estimated feed intake for a pig weighing $25 \mathrm{~kg}$ and eating $1 \mathrm{~kg}$ feed $/ \mathrm{d}$ ad libitum, i.e. around 10 feed intakes of $100 \mathrm{~g}$ each.

In conclusion, this study confirms the possible use of amoxicillin for oral treatments in pigs via feed, provided that adequate formulations such as the coated premix tested here prevent degradation of the active ingredient during feed manufacture.

\section{Analytická kontrola krmiva starter pro prasata medikovaného amoxicilinem}

Koncentrace amoxicilinu v krmivu pro prasata - starter medikovaném premixem s obalovaným amoxicilinem byly stanoveny dvěma nezávislými laboratořemi. Analytická metoda byla předtím převedena z jedné laboratoře do druhé. Výsledky mezi oběma laboratořemi byly konzistentní, dokládající robustnost stanovení. Průměrná koncentrace amoxicilinu v krmivu před a po peletizaci byla vyšší než 90 \% teoretické hodnoty, potvrzující dostatečnou stabilitu účinné látky v testované obalované formě.

\section{Acknowledgement}

The authors thank Mr Hruby (SKS, Marefy, Czech Republic) for his support in manufacturing and sampling the medicated feed.

\section{References}

BOUSQUET E, DERRIEU G, RAYNIER B, SEGOT C, LEMAIRE F, SANQUER A, CASADO P, COLL MASVIDAL T, MORILLO ALUJAS A, CANO LOPEZ G, VILLALBA MATA D, GOUTALIER J, COMBEAU S 2006: Comparative study of different amoxicillin premixes (homogeneity and stability in feed). In: $27^{\text {th }}$ Anaporc Symposium. Badajoz, Spain, pp. 185-188.

De BAERE S, De BACKER P 2007: Quantitative determination of amoxicillin in animal feed using liquid chromatography with tandem mass spectrometric detection. Anal Chim Acta 586: 319-325

DERRIEU G, RAYNIER B, ASCHER A, GARDEY L 2000: Interest of a stabilized amoxicillin in feedstuffs manufacturing. Rev Med Vet 151: 109-117

DOUSA M, HOSMANOVÁ R 2005: Rapid determination of amoxicillin in premixes by HPLC. J Pharm Biomed Anal 37: 373-377

EUROPEAN PHARMACOPOEIA 2005: Amoxicillin trihydrate. In: European Pharmacopoeia, supplement 5.3. $5^{\text {th }}$ ed. European Directorate for the Quality of Medicines and Healthcare, Strasbourg, pp. 3440-3442

HIGGINS R, GOTTSCHALK M 2006: Streptococcal diseases. In: STRAW B, ZIMMERMAN JJ, D’ALLAIRE S, TAYLOR DJ (Eds): Diseases of Swine. Blackwell Publishing, pp. 767-783 
MARIE J, MORVAN H, BERTHELOT-HERAULT F, SANDERS P, KEMPF I, GAUTIER-BOUCHARDON AV, JOUY E, KOBISCH M 2002: Antimicrobial susceptibility of Streptococcus suis isolated from swine in France and from humans in different countries between 1996 and 2000. J Antimicrob Chemother 50: 201-209

PEJSAK Z, JABLONSKI A, ZMUDZKI J 2005: Drug sensitivity of pathogenic bacteria isolated from the respiratory system of swine. Med Wet 61: 664-668

RAPP-GABRIELSON VJ, OLIVEIRA SR, PIJOAN C 2006: Haemophilus parasuis. In: STRAW B, ZIMMERMAN JJ, D'ALLAIRE S, TAYLOR DJ (Eds.): Diseases of swine. Blackwell Publishing, pp. 681-690

SCHWARZ S, ALESÍK E, GROBBEL M, LÜBKE-BECKER A, WERCKENTHIN C, WIELER LH, WALLMANN J 2007: Antimicrobial susceptibility of streptococci from various indications of swine, horses, dogs and cats as determined in the BfT-GermVet monitoring program 2004-2006. Berl Munch Tierarztl Wochenschr 120: 380-390

SCHWARZ S, BÖTTNER A, GOOSENS L, HAFEZ HM, HARTMANN K, KASKE M, KEHRENBERG C, KIETZMANN M, KLARMANN D, KLEIN G, KRABISCH P, LUHOFER G, RICHTER A, SCHULZ B, SIGGE C, WALDMANN KH, WALLMANN J, WERCKENTHIN C 2008: A proposal of clinical breakpoints for amoxicillin applicable to porcine respiratory tract pathogens. Vet Microbiol 126: 178-188 
